\title{
ISTANBUL'S CURRENT STATUS AND POTENTIAL FOR BECOMING AN INTERNATIONAL FINANCIAL CENTRE
}

\section{Hasmet Sarigul}

Mevlana (Rumi) University

Faculty of Management

hsarigul@mevlana.edu.tr

\section{-Abstract -}

The Turkish government has been pursuing a goal to turn Istanbul into a regional centre for finance and then, an international one. However, creating an international financial centre where international demand and supply of funds meet is not an easy process. In this context, we aimed to examine the current status and the potential of Istanbul to become an international financial centre. In order to reach the aim of the study, firstly, the characteristics of an international financial centre have been explained and a brief overview of the Turkish government's official plans of development of the international financial centre have been given. Then, the strengths, weaknesses, opportunities and threats of Istanbul have been analyzed. Finally, we have made assessments and put forward some suggestions.

Key Words: Istanbul, SWOT analysis, international financial center.

JEL Classification: F23, F33, F53, G15, G20.

\section{INTRODUCTION}

Modern telecommunication facilities and the presence of large multinational financial institutions in key time zones around the globe have created a continuous, round-the-clock world financial market. (Park, 2011:2) In other words, the continious reduction in the costs and difficulties of transport and communication over the last 200 years has favored the formation of a single world financial market.(Kindleberger, 1978;15)

The Turkish Government endorsed the idea of turning Istanbul, which is the best known and the largest city and the national financial centre(NFC) of Turkey, to one of those international financial centres. The government formed an 
organisation structure and started to work on the target of making Istanbul a regional financial centre (RFC) within 10 years and one of five or six most important international financial centres (IFC) within 30 years. In the this context, the aim of the study is to examine the current status and the potential of Istanbul to become an IFC.

The structure of the study is as follows. Chapter two provides a brief description of International Financial Centre (IFC), overview of the activities of IFCs and presents a typology of financial centres. In section three, a brief overview of The Turkish government's official plans of development of the international financial centre has been given. Section four evaluates the strengths, weaknesses, opportunities and threatments of Istanbul for becoming an IFC. The paper ends with some concluding remarks.

\section{DESCRIPTION, CHARACTERISTICS AND TYPOLOGY OF AN IFC}

\subsection{International Financial Centre}

There is no consensus on a single definition of IFC yet. But in general "a financial centre is a place where providers of and customers for financial services meet to transact business. This definition includes both domestic financial centres and international financial centres".(Reed, 1998:41) According to Karen Lai "a financial centre is a conglomeration of financial and service enterprises and corporate headquarters, particularly foreign ones. Rather than providing retail services such as branch banking, a financial centre focuses on providing high level financial and professional services that serve a much larger area at national, regional and even global scales, as evident in the presence of head offices of multinational financial and nonfinancial institutions"'. (Lai, 2006:3) Jao defines an IFC as "a place in which there is a high concentration of banks and other financial institutions, and in which a comprehensive set of financial markets are allowed to exist and develop, so that financial activities and transactions can be effectuated more efficiently than at any other locality". (Jao, 1997:15)

An IFC has some characteristics. It is a centre; (Fakitesi, 2009:4)

- from which international financial business can be conducted profitably, easily and efficiently,

- with skilled management and intellectual talent covering business, finance and interdependent services such as legal and accounting, to provide 
multi-disciplined teams that facilitate large cross borders transactions in the shortest possible time frame,

- with deep liquid and sophisticated capital market and world competitive tax and regulatory regimes with foreign investment and offshore business flow,

- that can add significant value to financial services provided from it, through a workforce that can respond promptly and in an innovative manner,

- with the World's best telecommunications and IT capacity and imbued with plentiful, well educated, multilingual workforce,

- where all facets of financial services: CEOs; senior traders, regional headquarters, treasury operations, data processing, support functions and call centers, can be located efficiently,

- with convivial and alluring environment for business.

Yoon-shik Park emphasises that international financial centres are distinguished from their domestic counterparts by three important characteristics. (Park, 2011:2)

- First, they deal in various major currencies of the world, not just the currency of the country where a centre is located. In this way, financial transactions in the centre are not directly linked with the domestic banking system. Since all international financial centres deal in external, or offshore, currencies compared with the purely domestic, or onshore, currency of a national financial center, one may also call them offshore financial centers.

- Second, most of the financial transactions conducted in foreign currencies in these centres are generally free of the taxes and exchange controls that are imposed on purely domestic financial transactions. This asymmetry in government regulations between offshore and domestic financial markets has frequently been cited as a major reason for the phenomenal growth of the eurocurrency and eurodollar markets and offshore financial centres during the recent decades.

- Third, international financial centres provide various financial services to both resident and nonresident clients. The scope of interface between residents and their own international centre is closely monitored by the host government, which has to balance its conflicting objectives of 
promoting its international financial centre and controlling potential abuses by residents.

\subsection{Types of International Financial Centres}

There are different types of international financial centres. The International Monetary Fund distinguishes three categories among them: international financial centres, regional financial centres (RFCs), and offshore financial centres (OFCs).

From a geographical perspective Jao classifies international financial centres (IFCs) as global centres and regional centres(GFCs). He also classifies IFCs as traditional centres, financial entrepôts and offshore banking centres from a historical perspective. (Jao, 1997:15),

Global Financial Centre : A GFC is an intense concentration of a wide variety of international financial businesses and transactions in one location.These are centres that genuinely serve clients from all over the world in the provision of the widest possible array of IFS.( Yeandle e.a., 2005:11)

Regional Financial Centre : A RFC is a central location where there is a high concentration of financial institutions and capital markets that allow financial transactions in the region that take place efficiently.(Hew, 2001:1)

Offshore Financial Centres : An OFC is a centre that hosts financial activities that are separated from major regulating units (states) by geography and/or by legislation. This may be a physical separation, as in an island territory, or within a city. (Hampton, 1996:4)

\section{Istanbul Financial Centre Project}

Turkey; an entrance gateway to the east for the Westerns and to the west for the Easterns is the biggest market in its region. The great majority of manufacture, service and financial activities in Turkey take place in and around Istanbul. The city that has grown to be one of the giant metropoles in the world and has been described as the economic and business capital of Turkey. It is a city that 20 per cent population of Turkey lives in, generates about 27 per cent of economic output, 40 per cent of tax revenues and around half of exports of Turkey.

The Turkish government has been pursuing a goal to turn Istanbul into a regional centre for finance and then, an international one. As a long term Project, the international financial centre has been planned to be regionally dominant within 
10 years, and to be one of five or six most important international centres within 30 years. In accordance with this goal, The Turkish government has been working to improve the Turkish tax system, legal and fiscal environment, political and economic stability and regulatory framework.

\section{A SWOT Analysis about Istanbul's IFC Project}

There are some studies about Istanbul International Financial Centre Project. Suat and Dilek Teker had examined and evaluated the City of Istanbul's potential as a good candidate of regional and/or global financial centre in their study titled "Istanbul as an International Financial Centre: Pros and Cons" in 2011. Another one is "A Study on Fixing Competitive Level of Istanbul With International Financial Centres" by Huseyin Yilmaz in 2010. Sudi Apak and Gorkem Elverici had also analyzed Istanbul's Financial Centre Project in 2008.

In order to strengthen all these studies and to contribute to all, we measured the idea to turn Istanbul to an IFC by using SWOT analysis.

\section{Strengths}

- In 2012 Global Cities Index and Emerging Cities Outlook Istanbul was reported to be one of the most significant urban vectors in the next decade. It has long been described as the hinge between west and east, with a rich imperial culture and deep knowledge about how to govern such intersections,

- Istanbul has two modern airports that are well connected to the financial, business centres and other major global cities. According to the 2010 Annual Report of ICAO, Istanbul is the 19th city in the world by 20.343 .000 international airway passangers,

- The city has a favourable time zone of GMT+2. Its geographical location close to many growing markets in the Middle East, Gulf, North Africa, Eastern Europe, Central Asia and Black Sea Region is one of the

\section{Weaknesses}

- The country's low savings rate and current account deficit financed by shortterm capital flows,

- Lack of English proficient workforce. The English Proficiency Index (EPI) ranked Turkey $43 \mathrm{rd}$ among 44 countries in 2011,

- Relatively weak stock market capitalization, private sector bond market and derivatives. According to the World Federation of Exchanges (WFE) market statistics 2011, Istanbul Stock Exchange's market value was the $32^{\text {nd }}$ and number of listed companies is the 34 th among 51 . The value of private sector bonds was the $21 \mathrm{st}$ among 37 stock exchanges in the World in 2011,

- Relatively weak nation brand. Turkey ranked 33rd among 50 countries in Anholt 


\begin{tabular}{|c|c|}
\hline advantages for Istanbul, & National brands index for 2011 \\
\hline $\begin{array}{l}\text { - The affects of commitment EU accesssion } \\
\text { such as; single market integration, change } \\
\text { in the macro-economic policy framework } \\
\text { and change in the economic governance } \\
\text { structures, }\end{array}$ & $\begin{array}{l}\text { - Quite complicating tax system. An } \\
\text { excessive number of documents are } \\
\text { required to accompany tax statements on a } \\
\text { monthly, quarterly and also yearly basis } \\
\text { from tax payers by tax offices, }\end{array}$ \\
\hline $\begin{array}{l}\text { - Turkey is one of the largest economies in } \\
\text { the World as a member of G- } 20 \text { and } \\
\text { Istanbul is responsible for } 27 \text { per cent of } \\
\text { Turkey's GDP, }\end{array}$ & $\begin{array}{l}\text { - The traffic congestion is a great problem } \\
\text { in Istanbul. The transportation in Istanbul } \\
\text { is mostly based on buses, minibuses, taxis } \\
\text { and private automobiles, }\end{array}$ \\
\hline $\begin{array}{l}\text { - Strong will of Turkish Government to } \\
\text { establish Istanbul Financal Centre, }\end{array}$ & $\begin{array}{l}\text { - The lack of availability of a sufficient } \\
\text { number of lawyers expert on the financial }\end{array}$ \\
\hline $\begin{array}{l}\text { - Sturdy and profitable banking sector. } \\
\text { Strong capital adequacy of Turkish Banks } \\
\text { with the } 16,4 \text { percent average ratio in April }\end{array}$ & $\begin{array}{l}\text { services industry, } \\
\text { - Foreign lawyers are only allowed to be in } \\
\text { the courts as advisors, }\end{array}$ \\
\hline 2012, far above the legal limit of 8 percent. & $\begin{array}{l}\text { - There is no foreign-owned company } \\
\text { listed in the Istonbul Stock Exchange }\end{array}$ \\
\hline $\begin{array}{l}\text { - Improved quality of prudential banking } \\
\text { and supervision, }\end{array}$ & $\begin{array}{l}\text { listed in the Istanbul Stock Exchange, } \\
\text { - Lack of specialist arbitration courts. }\end{array}$ \\
\hline $\begin{array}{l}\text { - Better commercial banking in comparison } \\
\text { with the other IFC competitors in the } \\
\text { region, }\end{array}$ & \\
\hline $\begin{array}{l}\text { - About } 20 \% \text { of Turkey's young and } \\
\text { increasingly educated labor force are } \\
\text { residing in Istanbul. There is no numerical } \\
\text { shortage in the labor market, }\end{array}$ & \\
\hline $\begin{array}{l}\text { - High quality and skilled labor force in the } \\
\text { field of banking. COL Index of Turkey } \\
\text { indicates accesibility to this labor force } \\
\text { with comparitavely lower costs, }\end{array}$ & \\
\hline $\begin{array}{l}\text { - COL Index rates Turkey for cheaper rates } \\
\text { in comparison with most of the G } 20 \\
\text { countries. Financial services professionals } \\
\text { can enjoy similar or higher standards of life } \\
\text { from other IFCs with lower costs, }\end{array}$ & \\
\hline $\begin{array}{l}\text { - There is no restriction on the acquisiton of } \\
\text { real estate by foreigners. }\end{array}$ & \\
\hline
\end{tabular}




\section{Opportunities}

- Turkey's strategic geographic location between the energy supply (Russian Federation, Caspian and the Middle East) and the demand (the European Union countries and world markets via Mediterranean,

- Establishment of Istanbul as the first operations center of the International Finance Corporation apart from its headquarters in Washington, D.C. to serve clients in 30 countries in Europe, Central Asia, the Middle East and North Africa,

- Its geographical location enables to overlap the first four hours of the business day with the Asian countries and the other four hours with European countries,

- Turkey's huge growth potential and fastgrowing economy offer high growth potential for financial services,

- The equity market is still underdeveloped relative to its potential and offers opportunities,

- There is a huge growth in the insurance sector and a huge upside potential in mortgage and pension funds,

- Close cultural and linguistic ties with the rapidly developing Turkic countries create strong communication opportunities,

- Turkish expatriates work in financial services abroad. The estimated number of them is about 20.000 .

\section{Threats}

- Moscow's becoming a regional financial centre for the CIS countries and growing financial sector in Russia,

- The loss of skilled individuals through brain drain or student non-return,

- Earthquake risk and its expected physical, social, economic, and industrial losses in Istanbul,

- Frequent changes to tax law increasing uncertainty,

- The perception of weak tax morality which puts a comparative disadvantage.

\section{CONCLUSION}

The result of the SWOT analysis shows that Istanbul has significant strengths to become an IFC. It has been recognised that Istanbul is well with its geographical position, young and increasingly educated labor force, no numerical shortage in 
the labor market, high quality and skilled labor force in the field of banking, two modern airports that are well connected to the financial, business centres and other major global cities. There are also some strengths of the country that affects Istanbul possitively such as better commercial banking in comparison with the other IFC competitors in the region, sturdy and profitable banking sector, improved quality of prudential banking and supervision, cheaper COL which means similar or higher standards of life from other IFCs with lower costs for financial services professionals, some affects of commitment EU accession(single market integration, change in the macro-economic policy framework and change in the economic governance structures). However, the analysis also unearthed some important weaknesses. The country's low savings rate and current account deficit financed by short-term capital flows, lack of English proficient workforce, relatively weak stock market capitalization, private sector bond market and derivatives, relatively weak national brand, complicating tax system and traffic congestion are regarded as the weaknesses for Istanbul. The opportunities we diagnosed in the study are Turkey's huge growth potential and fast-growing economy, strategic geographic location between the energy supply and the demand the European Union countries and world markets via Mediterranean. The major threat has been regarded as the earthquake risk.

In order to convert weaknesses into strengths and to match strengths and opportunities;

- The problems of Turkey in financing current account deficit should be corrected,

- English proficiency of workforce should be increased,

- The brand image of Turkey should be improved,

- Stock market capitalization, private sector bond market and derivatives should be strengthened.

- Tax laws and practices should become more simple, clear and predictable,

- Traffic congestion in Istanbul should be solved,

- The international regulations and practices about finance and accounting should be adopted,

- Financial market transparency and accountability should be strengthened,

- Istanbul should become ready for a big earthquake,

- Technology and communications infrastructure should be strengthened. 
Finally, it can be concluded that Istanbul has a long way to go and there are many things to do before it can become an IFC.

\section{BIBLIOGRAPHY}

Apak, Sudi and Gorkem Elverici, 2008, “The Analysis of Istanbul's Financial Center Project', Istanbul, The Journal of Accounting and Finance, Vol.38, pp.9-20.

Deloitte Consulting, 2007, Istanbul International Financial Centre Feasibility Study, The Banks Association of Turkey.

Fakitesi, Tayo, 2009, "Building an International Financial Centre', Abuja, Panel Discussion on the Occasion of the 50th Anniversary of Central Bank of Nigeria.

Hampton Mark P., 1996, The Offshore Interface, Tax Havens in the Global Economy, New York, St. Martin's Press.

Hew, Denis, 2001, “Singapore as a Regional Financial Centre”, Tokyo, AT10 Research Conference.

IMF Monetary and Exchange Affairs Department, 2000, "Offshore Financial Centers-IMF Background Paper," Washington, D.C.,International Monetary Fund. Jao, Yu-ching, 1997, Hong Kong as an International Financial Centre, Evolution, Prospects and Policies, Hong Kong Economic Policy Studies Series, Hong Kong, City University of Hong Kong Press.

Kindleberger, Charles.P, 1978, Economic Response: Comparative Studies in Trade, Finance, and Growth, Cambridge, Harvard University Press.

Lai, Karen, 2006, "Developing Shangai As An International Financial Centre: Progress and Prospects", Nottingham, University of Nottingham China Policy Institute Discussion Paper 4.

Park, Yoon-shik, 2011, "Developing an International Financial Center to Modernize the Korean Service Sector', Korea Economic Institue Academic Paper Series.

Reed, Alexander P, 1998, Money and the Global Economy, Cambridge, Woodhead Publishing Limited. 
Teker, Suat and Dilek Teker, 2011, "Istanbul as an International Financial Center: Pros and Cons', Istanbul, Finans Politik ve Ekonomik Yorumlar, Vol.48, No.561, pp.57-68.

T.R.State Planning Organization, The Strategy and Action Plan for Istanbul Internatioal Financial Centre, 2009,State Planning Organization.

Yeandle, Mark, Michael Mainelli and Adrian Berendt, 2005, The Competitive Position of London as a Global Financial Centre, London, Corporation of London. Yilmaz, Huseyin, 2010, “A Study on Fixing Competitive Level of Istanbul With International Financial Centres', Istanbul, 8th International Knowledge, Economy\& Management Congress Proceedings, pp.850-864. 